\title{
INTER AND INTRASTATE CONFLICTS NEXUS: The Colombian Peace process, AS A MEANS TO PREVENT INTERSTATE CONFLICTS IN SOUTH AMERICA AND RETHINK REGIONAL SECURITY
}

Sandra Montoya Ruiz*

\section{Abstract}

The Colombian internal conflict case provides useful scenarios, realities and dynamics for nourishing the debate between those who treat internal and interstate conflicts as disconnected or totally independent phenomena and those who argue the frequent links between them. This policy paper is situated in the latter school of thought, and from that angle I shall argue the usefulness of perceiving the nexus between intrastate and interstate conflicts, and its applicability to the Colombian internal conflict. The paper highlights the importance of taking into account the strong nexus in order to prevent international disputes that put regional security at risk; it also suggests that the current Colombian peace process represents an historic opportunity for Colombia -and a great challenge for the Colombian society- while at the same time being an opportunity for thinking about a shared future in the South America region, which challenges the Colombian state and its performance at the international level.

Key words: Colombian internal conflict, peace process, interstate conflicts, regional security, state, shared future.

* Maestría en Asuntos Internacionales, Universidad Externado de Colombia. Docente e Investigadora, Centro de Investigaciones Socio-jurídicas, Facultad de Derecho, Universidad Católica de Colombia (Colombia). Grupo de Investigación "Persona, instituciones y exigencias de justicia”.sjmontoya@ucatolica.edu.co; politologa85mruiz@ gmail.com

Recibido: 1/03/2016/ Modificado: 26/04/2016/ Aceptado: 20/11/2016.

Para citar este artículo

Montoya Ruiz, S. (2017). Inter and intrastate conflicts nexus: The Colombian Peace process, as a means to prevent interstate conflicts in South America and rethink regional security. OPERA 20, pp. 5-33.

DoI: https://doi.org/10.18601/16578651.n20.02 
LOS NEXOS ENTRE CONFLICTOS INTER E INTRAESTATALES: EL PROCESO DE PAZ EN COLOMBIA COMO MEDIO PARA PREVENIR CONFLICTOS INTERESTATALES EN SURAMÉRICA Y REPENSAR LA SEGURIDAD REGIONAL

\section{Resumen}

El conflicto armado interno colombiano brinda escenarios, dinámicas y realidades que permiten nutrir el debate entre quienes tratan los conflictos interestatales e internos como fenómenos desconectados o completamente independientes, y aquellos que argumentan frecuentes nexos entre ambos. Este artículo se sitúa en la segunda postura, y desde allí se argumentará la utilidad de percibir los nexos entre los conflictos inter e intraestatales, y la aplicabilidad de esta postura para el conflicto armado interno colombiano. El artículo resalta la importancia de incluir los fuertes nexos entre los conflictos para la prevención de disputas internacionales que pongan en riesgo la seguridad regional; así mismo, sugiere que el actual proceso de paz colombiano representa una oportunidad histórica para el país -que desafía fuertemente a la sociedad colombiana-, y, al mismo tiempo, representa una oportunidad para pensar en un futuro compartido en la región suramericana, que desafía al Estado colombiano y su desempeño en el plano internacional

Palabras clave: conflicto armado colombiano, proceso de paz, conflictos internos, conflictos interestatales, seguridad regional, Estado, futuro compartido.

\section{INTRODUCTION}

Analyses concerning the occurrence of interstate conflicts in countries dealing with active internal conflict(s) have evolved slowly over the last decades (Gleditsch, Skrede and Schultz, 2008). Although a large body of work on violence and conflicts has accumulated diverse approaches, they have tended to treat the two levels of conflict as disconnected phenomena (Gleditsch et al., 2008). However, there is a growing interest in the frequent connections between both levels, in particular after the Cold War period. In contrast to the initial very realist approaches, the Colombian internal conflict case has challenged their assumptions for decades. Indeed, this conflict provides useful scenarios and dynamics for nourishing the debate between those who treat the two types of conflicts as totally independent phenomena and those who argue the frequent links between internal and interstate conflicts. This policy paper is situated in the latter school of thought, and from that angle I shall argue the usefulness of perceiving the nexus between intrastate and inter-state conflicts, and its applicability to the Colombian intrastate conflict. Thus, the paper highlights the importance of taking into account the strong nexus in order to prevent international disputes that put regional security at risk.

After a brief description of this nexus, and how its characteristics are applicable in the Colombian conflict, the discussion will move to consider the meaning of these findings in preventing the likelihood of interstate disputes in South America. I shall particularly 
draw attention to the current Colombian peace process as a means of conflict prevention in the region. The analysis leads to quite different conclusions as compared to those that result from the adoption of perspectives that treat intrastate conflicts as disadvantages or obstacles for seeking/achieving cooperation. Consequently, it is suggested that the current Colombian peace process is indeed an historic opportunity for Colombia, while at the same time being an opportunity for a shared future in the region.

The paper is organized into two main parts. First, it outlines the intrastate Colombian conflict, its treatment by the state and the 'intermestic' ${ }^{1}$ nature of the conflict, while it underlines the combination of domestic and international arenas in the strategies followed by the state. In order to give a multi-dimensional approach on the Colombian conflict, I will briefly describe: a) the rationale of illegal armed groups and their financing sources, b) intervention, externalization strategies and collateral effects, c) the role of territorial proximity on the border zones. In addition, it is necessary to mention the usage of bordering areas by the illegal armed groups which have appeared in this dynamic context. All of those elements have been -but not simultaneously, and with different levels of influence- sources of tension in the bilateral relations between Colombia and its neighboring countries (See: Annex 1). All of them are considered by different authors as civil war issues and dynamics that can also have an impact on the occurrence of international disputes. In the second part, I will consider the current peace process with the FARC as an historic opportunity at local, national and regional levels. For this purpose, an overview of the current peace process will be provided. Then, the role of the state as an agent of change in Colombia and beyond will be underlined.

On the basis of previous research, the presence of all of these elements suggests challenging but constructive ways for understanding the Colombian internal conflict and its derivations. One of the possible paths is proposed in this paper, based on findings pointed out by Gleditsch, Salehyan and Kenneth, Dhiel, Singer and Garhnam, Vasquez and Valeriano, Hensel, Wood, Starr, Pardo and Carvajal, Echandía, OAsis ${ }^{2}$, the Colombian Foreign Affairs Policy Mission 2010², Cabrera, Valenzuela, and others. From their findings, and by taking into account the ongoing Colombian peace process and challenges, I will argue that the lack of resolution of the Colombian internal conflict increases the likelihood of interstate conflicts in the South

\footnotetext{
1 This concept has been introduced in International Relations in reference to political affairs that are of both international and domestic concerns.

2 OASIS - Observatory of International Systems Analysis, University Externado of Colombia.

3 The Colombian Foreign Affairs Ministry commissioned, in 2009, seven outstanding experts, in order to develop a more effective foreign affairs policy. The commissioners were: Camilo Reyes, Gustavo Bell, Hernando José Gómez, Juan Gabriel Tokatlian, Mauricio Reina, Sandra Borda and Socorro Ramirez. See: Bell et al. (2010).
} 
American region, since there are characteristics that tend to result in a strong nexus between intrastate and interstate conflicts. However, preventing the latent risk of interstate disputes in the region seems to be possible by way of supporting the current Colombian peace process and the resolution of the conflict.

Although this paper attempts to bring to the fore the importance of the Colombian peace process, the paper borrows constructivist and idealist lenses, and through them treats social change as possible and dissimilar in the different 'degrees of statehood' (Clapham, 1998). The kind of support required for seeking this goal will be, in practice, defined by the extent to which the stakeholders, whether public or private, would be able and willing to participate at the national level. Not only is this participation required, but the stakeholders are also called upon to be a part of the process belonging to the national level while some of them are also involved in international/global levels. Care needs to be taken to ensure a responsible and ethical path in which multilateral, national and local actors respond and perceive to what extent they have to be involved with the successful resolution of the Colombian conflict.

\section{INTERSTATE AND INTRASTATE NEXUS IN THE COLOMBIAN CONFLICT}

\section{Intrastate Colombian conflict, state treatment and 'intermestic' nature}

The Colombian internal conflict, which has its roots in the 1950s, has passed through different stages and has been marked by the involved actors. According to Pardo and Carvajal (2004, p. 158), five consecutive presidents had endeavored negotiation processes with the main Colombian guerrillas groups FARC and $\mathrm{ELN}^{4}$, all of them resulting in strengthening of the insurgent groups. From 1980s, the wrongly named "paramilitary groups" 5 were strengthened, while in 1990's they acquired an articulate political discourse with the establishment of the $\mathrm{AUC}^{6}$. Indeed, "in the last two decades of $20^{\text {th }}$ century, armed illegal groups were increasing their presence in the territory, the number of fronts and members [...] their consolidation was achieved through natural resources, legal (oil and gas) and illegal (coca and poppy). The war economies provided them with the means to finance their war strategies and plans"7 (Echandía, 2006, p. 11).

\footnotetext{
4 FARC, if translated to English, Revolutionary Armed Forces of Colombia, while for ELN, National Liberation Army.

5 The paramilitary groups are referred to as an official strategy of fighting insurgents by involving civilians; therefore, its applicability is not clear for the Colombian case. In fact, their counter-insurgent character is relativized by Echandía, as it indicates that their objective is related to the protection (expansion) of drug trafficking, and their presence in zones not operated by the guerrillas. See: Echandía (2006).

6 AUC means United Self-defenses of Colombia.

7 Original in Spanish "En las últimas décadas del s. xx, los grupos alzados en armas incrementaron su presencia en el territorio del país y el número de frentes y los integrantes en sus filas [...] lograron consolidar en torno a
} 
The Colombian official strategies for combating illegal armed groups have not been the same. Most significantly, whilst the Colombian governmental strategies have mainly focused on combating guerrillas, the "paramilitarism/self-defense" phenomenon and its relation with violent dynamics were being postponed in the public debate on violence by official analyses of national security strategies. In 2003 this situation seemed to change. During the first presidential period of Alvaro Uribe Velez, "paramilitarism" was recognized as source of violence, and its organizations as political actors. Hence, a negotiation process with the "paramilitary groups" was perceived as necessary, as were plans of disarming, demobilization and reparation to victims.

The official Colombian anti-insurgency strategy has simultaneous and inseparably mixed domestic and international affairs, or what is called "intermestic issues" by Bayles (1997, p. 309). In the words of Pardo and Carvajal:

The Cuban revolution in 1959, the Sino-Soviet split in the early 1960 s and the Sandinista victory in the 1978 [...] have some influence on the emergence of the Colombian insurgence [...] as similarly do [:] the FSLN defeat in the Nicaraguan presidential elections, the peace agreements in the Salvador, the UssR collapse and the Cuban economic crisis resulting from the dismantling of Soviet subsidies [...] influenced guerrillas dynamics in the 1990s (Pardo \& Carvajal 2004, p. 163) ${ }^{8}$.

Regarding the treatment of the internal conflict, the decision-making processes for each of the presidential administrations was framed differently. Specifically, the governmental decision of internationalizing the conflict or keeping it in domestic arenas was strongly influenced by current historical international contexts. Between the 1960s and 1980 s, the war against communism determined the international agenda for the Western Hemisphere. In the 1980s, drug trafficking was positioned as a collective objective which the international community was required to combat. Subsequently, in the 1990s, illegal drugs and humanitarian crises were in the sight of the international community. At the beginning of $21^{\text {st }}$ century, the war against international terrorism is the top issue in the international agenda. Consequently, in Colombia, and according to Pardo and Carvajal "since the first peace process in 1982, the successive presidential administrations sought to prevent a 'downward spiral' in the domestic war that could stimu-

recursos naturales, tanto lícitos -oro y petróleo- como ilícitos -coca y amapola-, economías de guerra que les permitieron contar con los medios para financiar sus estrategias y planes de guerra”.

$8 \quad$ Original in Spanish, "La revolución cubana de 1959, el rompimiento chino-soviético a comienzos de la década de los setenta y el triunfo de los sandinistas en Nicaragua en 1978 [...] ejercieron alguna influencia en la creación de la insurgencia colombiana [...] así como la derrota del FSLN en las elecciones presidenciales nicaragüenses, los acuerdos de paz en El Salvador, el colapso de la URss y la crisis económica cubana tras el desmantelamiento de los subsidios soviéticos [...] tuvieron influencia en la dinámica de los movimientos guerrilleros en la década de los $90 ”$ 
late an external military intervention in the country" (Pardo \& Carvajal, 2004, p. 169). Thus, as the authors pointed out, Colombia's role and perspective in the Central American conflict resolution via Contadora ${ }^{10}$, made it possible to prevent a "Central-Americanization" of the Colombian conflict.

It should be noted that in the 1980s, the governmental approaches to the internal conflict were separated from those used in combating drug trafficking, "based on a conviction according to which the guerrilla's fight pursued policy objectives and not economic benefits [but at the same time that] by accepting those links it might decrease the probability of concluding the internal conflict via negotiation" 11 (Pardo \& Carvajal, 2004, p. 169). Indeed, since the second half of the 1990s the state decision of maintaining the Colombian conflict internationally isolated changed. As a result of this shift, at the end of the decade the Colombian president Pastrana (1998-2002), supported by many important actors representing different arenas and including legal cooperation and humanitarian mediations figures, facilitated favorable perspectives in the policy arena to start peace talks with the FARC.
However, the strengthening of illegal groups and the positioning of drug trafficking in their financing sources took place over the 1980s. An explosive combination of factors occurred in this context, among them: benefits of an interdependent and globalized economy, advances in communications, diversification of both drug trafficking markets and its stakeholders' nature. In spite of such a combination, inside the attempts to explain the disappointing results of the peace process during the Pastrana administration, an important current of thought tended to draw attention to a dysfunctional administrative and political management of the process. Through this current of thought, Colombian specialists, including Echandía, have addressed the relevance of the failure of negotiations of that period with the FARC. The author suggested that the failure laid bare that:

[T] he FARC [was] far from a final negotiation [...] from their political and ideological perspective [...] they deeply mistrust the Colombian elites [while the FARC] are betting for making the contradictions deeper [and they] consider that Colombia is not a democracy [.] Therefore their political participation or a legal opposition cannot be guaranteed [This guerilla] will insist on

9 Original in Spanish "desde el primer proceso de paz en 1982, las sucesivas administraciones presidenciales buscaron evitar: empeorar la guerra doméstica y conducir a una intervención militar extranjera en el país".

10 The Contadora was a diplomatic initiative founded in 1983 by the foreign ministers of Colombia, Mexico, Panama and Venezuela. The initiative emerged to deal with the military conflicts in El Salvador, Nicaragua and Guatemala. Drawing international attention to those conflicts and pressured for a softening of the militarist stance of the USA in the region, the peace plan received the backing of a large amount of Latin American countries, the United Nations Security Council and the General Assembly. See Roy (1999).

11 Original in Spanish "con base en la convicción de que la lucha guerrillera perseguía objetivos políticos y no la búsqueda de beneficios económicos [pero al mismo tiempo,] aceptar oficialmente dichos vínculos podía restringir la posibilidad de finalizar por vía negociada el conflicto interno". 
confrontation which, according to their calculations, will increase their power until achieving a strategic balance with the state, in order to pave the way for negotiation (Echandía, 2006, p. 158) ${ }^{12}$.

This was the scenario that, surrounded by collective frustration, welcomed the $21^{\text {st }}$ century, and fueled Colombian public opinion of preference for a military solution to defeat the FARC. In contrast, the public debate on violence associated with "paramilitary groups" continued to be kept in hiatus. This is the scenario, as were the international consequences of the events for September $11^{\text {st }} 2001$ (i.e., the global war against terrorism and a greater legitimacy for military means) that led to the election of Uribe Velez as president of the Republic in 2002. The Uribe Velez military strategy proposed as primary objective "to gain territorial control in the southeast part of the country by fighting the guerrilla's fronts with historical presence there [, while] the guerrillas intended to dilute the military efforts" ${ }^{13}$ (Echandía, 2006, pp.158-159).

Nowadays, the presidency of Santos Calderon (2010-2014 and 2014-2018 periods), in conjunction with highly important military blows to the FARC by the Colombian official forces, have opened the gate for negotiations with the guerrillas. The Colombian state has officially recognized the current internal conflict, dealing with a great variety of actors, and formulating/implementing a multilevel public policy for the victims of the internal conflict, their reparation, and reconciliation, and truth-seeking.

Under this renewed scenario, it is imperative to realize that "the Colombian internal conflict has had negative impacts on the approach to security policy [, the Colombian state approaches] have not [always] been shared by some countries in Europe and in the region, which has negatively affected the international insertion of Colombia in the world"14 (oAsis, 2008, p. 20). Indeed, contributing toward purposeful understandings of the Colombian internal conflict supports this academic exercise. To this end I will give a broader approach to: a) the rationale of illegal armed groups and their financing sources, b) intervention, externalization strategies and collateral effects, c) the role of territorial proximity on the border zones.

12 Original in Spanish: "las FARC [estaba] muy lejos de una negociación en firme [...] desde su perspectiva política e ideológica, esta guerrilla desconfía profundamente de la clase dirigente colombiana, [las FARC] le apuesta a la profundización de las contradicciones [...] considera que no existe democracia en Colombia [Esta guerrila] insistirá en la confrontación que, de acuerdo con sus cálculos, le permitirá aumentar su poder hasta alcanzar el equilibrio estratégico con el Estado para allanar el camino de la negociación”.

13 Original Spanish passage: "lograr el control territorial del suroriente del país combatiendo a los frentes guerrilleros que cuentan con una presencia histórica en esta región... [Mientras] la guerrilla pretende diluir el esfuerzo militar desplegado“.

14 Original in Spanish: "el conflicto armado Colombiano ha tenido un impacto negativo sobre el enfoque que se le ha dado a la política de seguridad. Este enfoque no ha sido compartido por algunos países europeos y del vecindario, lo que ha incidido negativamente en la inserción internacional ". 


\section{The rationale of illegal armed groups and their financing sources}

In the view of Echandía (2006), although natural resources ease the emergence of illegal armed groups, they themselves do not have sufficient explanatory power to understand the Colombian case. According to Echandía (2006), the armed confrontation in Colombia has not been framed in a linear evolution; instead, there are successive strategic ruptures that originate changes in the actors' modus operandi. Under careful mapping and analysis of the insurgent groups' evolution in Colombia, Echandía (p. 249) found that "the guerrillas have launched strategies in which are recognized at least three purposes: achieving a high dispersion of the fronts, diversifying sources of funding, and increasing local influence" 15 .

The sources of financing of illegal armed groups in Colombia have been nourished by drug trafficking, but also by other sources. Paraphrasing Echandia (2006), particularly since 1980s, the FARC included cocaine as a financing source into their expansion strategy. Additionally, there are incomes derived from controlling areas associated with livestock, commercial agriculture, farming and gold, and smuggling in bordering and coastal areas. Conversely, the strengthening of the ELN is more associated with the extortion of the foreign oil companies responsible for the
Caño-Limón-Covenas pipeline construction (Echandia, 2006). Indeed, these findings seem to be in line and give special validity to what Le Billion suggested:

[T] he motivation and funding of conflict is facilitated because primary commodities are often highly amenable to taxing and looting. This lootability arises in part from the fact that resources, and in particular extracted ones, are often easily accessible [...] with minimal bureaucratic infrastructure [...] the focus of military activities becomes centered on areas of economic significance. This has a critical effect on the location of conflicts [... while] complementing their traditional strategy of high mobility and location along international borders (Le Billion, 2001, p. 569).

The presence of resources and funding sources in the guerrillas' areas of influence have been determined by their strategic behavior and territorial control. However, this is not due exclusively to an economic rationale. In fact,

The guerrilla's presence and territorial expansion are not results of a random process, but strategic calculations based on political, military and economic concerns [...] the presence of these groups in many zones of the country was defined in advance (early 1980s) in their strategic plans, long time before they were aware about the economic potential of those zones [...] the guerrillas accomplished their expansion in the most important political and administrative centers of the country, and

15 Original in Spanish: "las guerrillas han puesto en marcha estrategias donde mínimo se reconocen 3 propósitos: lograr una alta dispersión de los frentes, diversificar sus fuentes de financiación y obtención de recursos y aumentar la influencia a nivel local”. 
developed armed activities in zones where oil, mining, illicit crops, bordering and important agricultural activity were present (Echandia, 2006, pp. 28, 32) ${ }^{16}$.

Regarding the "paramilitaries" or selfdefense soldiers, it is unavoidable to emphasize that in Colombia "the self-defense label is used for a wide range of armed organizations which want political treatment by the state, and justify their existence based on the guerrillas "harassment $[\ldots]$ hiding their very true interests linked to organized crime [...] in cases of organizations created by drug traffickers in rural areas, the [ir] functions [...] are clear" 17 (Echandía, 2006, p. 33). These deductions harmoniously combine with the perspective of Wood, for whom the war for commodities and other incomes make a negotiated settlement to the conflict difficult, since the large flow of money produced during war are not invested in peace. Consequently, as "insurgents would have to assume the cost of significant externalities [...] The legalization of such income flows may thus be very difficult, and insurgents may prefer to maintain their wartime forms of control despite the costs of ongoing war" (Wood, 2001, p. 249).

From what has been said above, while the relationship between natural resources, funding sources, and the presence of illegal armed groups is evident in the Colombian conflict, the violence associated with territorial control and armed confrontation indicates masked interests and rationales. Certainly, "conflict and violence have developed the highest intensity in the highest strategic areas, in which [:] the guerrillas seek to maintain their presence $[\ldots]$ the paramilitaries and criminal gangs have the intention of banishing them, and the Colombian public security forces deploy their action [in order] to regain control over these territories" ${ }^{18}$ (Echandía, 2006 and see the 2-5 Annexes). As a tragic consequence, the internal conflict actors have been using forced displacement as a strategic tactic and have produced dramatic results. As the National Center for Historical Memory of Colombia asserts (2013), there have been

16 Original in Spanish: "la presencia y expansión territorial de los grupos guerrilleros no es el resultado de un proceso aleatorio, sino de un cálculo estratégico en función de consideraciones políticas, militares y económicas [...] la presencia de estos grupos en muchas zonas del país se encontraba contemplada en los planes estratégicos definidos por las organizaciones hacia comienzos de los 80's, [...] la guerrilla logró extenderse a los centros políticoadministrativos más importantes del país y desarrollar actividades armadas en zonas petroleras, mineras de cultivos ilícitos, fronterizas y con importante actividad agropecuaria”.

17 Original in Spanish: "con el nombre de autodefensa se presenta una variada gama de organizaciones armadas, que buscan un tratamiento político por parte del Estado o justifican su existencia en razón del hostigamiento de la guerrilla para encubrir en muchos casos sus verdaderos intereses ligados al crimen organizado... en el caso de las organizaciones creadas a nivel rural por narcotraficantes, es claro que cumplen con otras funciones".

18 Original in Spanish: "el conflicto y la violencia, han registrado la mayor intensidad en las zonas que poseen un alto valor estratégico; en estas, las guerrillas buscan mantener su presencia ante el firme propósito de las autodefensas y bandas criminales de desterrarlas, mientras que la fuerza pública colombiana despliega su acción contra los grupos ilegales, para recuperar el control sobre estos territorios”. 
5,712,506 forced displacements (1985-2012), 177,307 civil deaths (1958-2012), 27,023 kidnappings (1970-2010), 25077 forced disappearances (1985-2012), 10,189 victims of anti-personnel mines $(1985-2012)$, and 1,982 mass murders (1980-2012).

\section{THE PRESENCE OF INTERVENTION AND EXTERNALIZATION STRATEGIES, COLLATERAL EFFECTS AND TRANS- BORDER ALLIANCES}

There have been different types of responses arising from different arenas of research in an attempt to clarify in which circumstances civil wars tend to lead to international disputes. One of the possible responses arises from an analysis of more than 400 militarized international disputes (MID) which coincided with civil wars. In their study, Gleditsch et al. (2008) found that those MID are often related to civil war issues, but also characterized by strategies of intervention and externalization and unintended spillover effects from internal conflict (collateral effects). Indeed, the authors underline that "the increased risk of interstate conflict associated with civil wars is primarily driven by states' efforts to affect the outcome of the civil war through strategies of intervention and externalization and not by an increase in conflicts over unrelated issues" (Gleditsch et al., 2008, p. 478).

State interventions in civil wars have different forms such as interstate military action, delegating part of their conflict behavior to foreign rivals of the rebel organizations and using rebel patronage (Gleditsch et al., 2008). It should be noted that rebel patronage has been increasingly favored since "rebels can provide information and expertise about the local population and terrain that states lack and can serve a legitimizing role by giving a domestic 'face' to the operation" (Gleditsch et al., 2008, p. 485). In the Colombian conflict, these forms of intervention might be identified for the FARC group, so that transbordering alliances have appeared in different stages of the conflict, as long as international assistance has been received by them from different sources. This leads to complex consequences, as long as international stakeholders of drug trafficking are involved.

Although direct interventions of foreign states are challenging to establish, events have occurred which put forward the involvement of senior officials from foreign states and their links with Colombian illegal groups. The data on Raul Reyes's computer (second in command of the FARC), seized in the military operation that transgressed the Ecuadorian border in 2008, is illustrative. In the computer, and according to what has been reported by the Colombian media, the FARC have woven international relations with thirty countries, including: Brazil, Bolivia, Costa Rica, Ecuador, Honduras, Nicaragua, Panama, Peru, Venezuela, and other Latin American countries, as well as countries in Europe and Asia. Concerning the neighboring countries (marine and territorial), it was found that:

Nicaragua [...] official aid poured by different sectors of the Nicaraguan government [...] protection and asylum to FARC members [...] weapons delivery [...] Costa Rica, 
the presence of large number of FARC members in that country [...] the Costa Rican public prosecutor office is investigating $[. .$.$] the FARC links with prominent politi-$ cians, entrepreneurs, and unionists...[p]roperties and 'businesses' of the guerrillas were detected [...] Panama [...] territory has been used to hold meetings in order to collect and launder money key links [and were detected] [...] for smuggling weapons into Colombia [...] Venezuela [...] for years, government sectors have delivered cash and weapons to the FARC [...] for instance, the director of Military Intelligence and the Disip (political police) guerrilla camps in the country [... have been found...] Ecuador [...]'Non-aggression pacts' between the FARC and the Ecuadorian government, as was written in an email by a guerrilla leader [...] selling weapons and explosives [...] Peru [...] the presence of FarC members in that country... assistance to the guerrilla factions in Peru...] dissents of Tupac Amaru Revolutionary Movement (MRTA) and the Revolutionary Left Movement (MIR)....the FARC used to use Iquitos as a quarry for militants, weapons, drug trafficking and as a place for recovering... in 2002, the FARC met [...] with members of the Shining Path [movement...] Bolivia [...] links between the FARC and the peasant leader Felipe Quispe ... the presence of guerrillas in Bolivia with the purpose of doing political indoctrination [but also] Bolivians were militarily trained in Colombia [...] Brazil [...] money has been donated to the FARC by leftist groups and unions [...] the guerrillas' nexus with Brazilian and Colombian drug traffickers (Semana Review, 2009) ${ }^{19}$.
In the meantime, the perception of Colombia as a threat for regional security has been taking hold since the internal conflict has given rise to unintended spillover effects with domestic, but also international, coverage. This characteristic has been pointed out by Gleditsch et al (2008) as involved in the occurrence of interstate military conflicts. The unintended spillover effects in the Colombian case are colossal, "about 35 thousand Colombians have been forcibly displaced to Ecuador [... ] where more than 50 soldiers and policemen have been killed by Colombian guerrillas, nearly 2 million Colombians are living in Venezuela where they have been increasing in numbers, in the border areas kidnapping, extortion and theft of vehicles and livestock have taken place [.] The guerrillas and the paramilitaries have been doing incursions in Panama, Brazil and Peru, with the purpose of supplying and training their troops" 20 (Pardo \& Carvajal, 2004, p. 156).

These facts corroborate the Gleditsch et al. (2004, p. 480) finding, "States experiencing civil war may externalize the conflict, directing military force outward to retaliate against others for supporting rebels and/or to conduct cross-border counterinsurgency operations $[\ldots]$ the fighting associated with civil wars can create unintended security spill-

19 The underlined text in the quotation was added by the author in order to highlight the countries. See the original article (Spanish) in the Annex 6, at the end of this paper (Semana Review, 2009).

20 Original in Spanish: "alrededor de 35 mil colombianos han sido desplazados hacia Ecuador más de 50 militares y policías han sido asesinados por miembros de la guerrilla colombiana, casi 2 millones de colombianos residen en Venezuela en donde se vienen incrementando, en la zona fronteriza, los secuestro, extorción y robo de vehículos y ganado; en Panamá, Brasil y Perú se han dado incursiones guerrilleras y paramilitares colombianas, cuyo propósito es abastecer y entrenar a sus tropas". 
overs that give rise to interstate tension". This finding helps to understand the Patriot Plan rationale during Uribe Velez's presidency, through which seven high mountain battalions and twenty-seven mobile brigades cut the strategic mobility corridors of the FARC, isolating them in border areas with Brazil, Ecuador and Venezuela (Instituto de Asuntos Geoestratégicos y Asuntos Políticos, 2010, p. 6). At the end of 2009, the Colombian armed confrontation scenario,

covers peripheral $[\ldots]$ particularly near borders areas with neighboring countries [...] Among the twelve neighboring departments [...] three (Guainía, Vaupés and Boyaca ]departments] increased the number of combats in the period from 2008 to 2009 [...] irregular groups increased their armed actions significantly in eight departments [...] Nariño [department] in the border with Ecuador ranked first in the five departments with most armed activity, followed by Norte de Santander and Arauca [departments] bordering Venezuela; Putumayo [department] bordering Ecuador and Peru; and Choco [department] which borders Panama ${ }^{21}$ (Echandía et al., 2010, pp. 148, 165).
Complementarily "the actions of the FARC in border areas increased by $80.12 \%$ between the Pastrana [1998-2002] and Uribe Periods, while the actions of the ELN [guerrilla] in the border areas were reduced by 55,2\%" 22 (Cabrera, 2009, p.189). However, paraphrasing Cabrera, Uribe's government underestimated the presence of illegal armed groups in these strategic areas, while some literature indicates that the rebels' presence in the border areas helps to prolong the conflict and causes negative externalities for the region (See Annexes 7-10).

In addition to this scenario, another ingredient showed up: "the confrontation claims [...], the increase of both fumigations and manual eradication of illicit crops [an issue of tension between Ecuador and Colombia] increased the resistance against the security strategy from neighboring au-

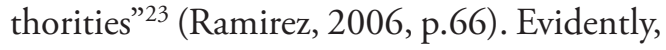
the careless Colombian fumigations, and its toxicity, caused important collateral effects in Ecuador borderlands, causing Ecuador to sue Colombia in the International Court of Justice

21 Original in Spanish: "el escenario actual de la confrontación armada comprende regiones periféricas y apartadas de la geografía nacional, en particular zonas próximas a las fronteras con los países vecinos [...] Entre los doce departamentos limítrofes34, únicamente en tres(Guainía, Vaupés y Boyacá) aumentó el número de combates de 2008 a 2009. [...] las acciones armadas de los grupos irregulares aumentaron de forma significativa en ocho de los doce departamentos fronterizos35. Entre los cinco con mayor actividad armada en 2009, Nariño, en la frontera con Ecuador, ocupa el primer lugar; seguido de Norte de Santander y Arauca, limítrofes con Venezuela; Putumayo, en límites con Ecuador y Perú; y Chocó, que limita con Panamá”.

22 Original in Spanish: "las acciones de las FARC en las zonas fronterizas incrementaron 80,12\% entre los periodos de Pastrana y Uribe [1998-2002], mientras que las acciones del ELN se disminuyeron 55,2\% en las zonas fronterizas”.

23 Original in Spanish : "las exigencias de la misma confrontación, y ha incrementado las fumigaciones y la erradicación manual de cultivos ilícitos [un asunto de tensión entre Colombia y Ecuadro, incrementó...] la resistencia existente entre los gobernantes vecinos a su estrategia de seguridad”. 
(2008), declaring Colombia's air fumigation a violation of Ecuador's sovereignty.

Moreover, the unintended spillover effects from the Colombian internal conflict relativized the state borders. One reason is related to the simultaneous and attached nature of regional-global phenomena that are strongly affecting Colombia. Seen from the national security angle, they represent a threat to Colombia. Speaking explicitly, "money laundering carried out by the Colombian armed groups in Peru, Ecuador and Bolivia, the weaponry delivery to the illegal organizations in which Venezuela, Paraguay, Peru and Brazil are involved; the illegal trade of weapons and chemicals [used in drug trafficking] which have to do with Europe and the United States of America, as well the illegal drugs consumption and their demand worldwide" 24 (Pardo \& Carvajal, 2004, pp. 156,157). By gathering the pieces of the internal conflict, the impact of implementing traditional and punitive perspectives on drugs supply gets much more complex and gives rise to more doubts about the effectiveness of the global war on drugs. Since then, the business' profitability has increased, but also the financial capability of the internal conflict actors and the unintended spillover effects from the Colombian internal conflict. In fact, during Santos' presidency, Colombia has played a leading role in promoting a regional and global debate on the war on drugs. Santos calls for recognition that between total war and legalization there exists a broad range of options worth exploring if one were to seek to take better care of drug consumers, protect the youth from drug abuse, collaborate to continue combating organized crime and provide alternative economic means to illegal crop farmers and vulnerable communities. This position was firstly presented

In 2012 during the Summit of the Americas in Cartagena, where the heads of state of the western hemisphere agreed to establish a mandate for the Organization of American States (OAS) to produce a report on options for refocusing the regional approach on drugs control. In 2013 the oas concluded the analysis and presented its report to the region. Since then, the report has been debated all across the Americas and has influenced public policy changes and adjustments in various countries, including Colombia [...] Colombia, Mexico and Guatemala lobbied to hold the 2016 general assembly special session, known as UNGASs, to seek a more "humane solution" to the drugs problem that goes beyond a focus on enforcement and criminalization (The Guardian, 2016).

However, the relationship between civil wars and militarized international disputes requires careful attention in analyzing the Colombian conflict, especially if the increased risk of interstate conflict is primary driven by states' efforts to affect the outcome of the

24 Original in Spanish: "las actividades de lavado de activos realizadas por los grupos armados colombianos en Perú, Ecuador y Bolivia, el suministro de armas a grupos ilegales colombianos en los que han estado relacionados Venezuela, Paraguay, Perú y Brasil; el comercio ilegal de armas e insumos químicos[usados en el narcotráfico] realizado desde Europa y Estados Unidos, así como el consumo de estupefacientes alrededor del mundo”. 
civil war, as was demonstrated by Gletisch and his colleagues. In the Colombian case, the conflictive nature of the relationship with neighboring states deserves to be followed by a strategic analysis in order to avoid taking this risk as a minor factor, but also to encourage the presidents in the region to see that this factor is not a game since it tends to lead to international disputes, as has occurred for 400 MID. Equally important is following the position on the Colombian peace process of states in the region to prevent any support, attempt or idea of intervention in the Colombian conflict. Therefore, maintaining the neighboring states' support for the Colombian peace process is crucial, as is turning the highly strained relationships between states into lowlevel conflictive or competitive/friendly ones. Pursuing those challenges requires solving common problems, i.e. money laundering, weaponry delivery to illegal and criminal organizations, illegal trade of weapons, chemicals and oil; but also dealing with the low human development in the Colombian border areas with its neighbors, i.e., effectively fighting poverty and increasing opportunities for working and studying. Indeed, the combination of the mentioned means seems to decrease the risk explained by Gletisch.

Complementary, and drawing on why foreign states would decide to support rebel groups in an internal conflict, Gletisch et al. (2004, pp. 484-485) identified five reasons: a) Proxy wars, b) Regime disputes, c) Irredentism d) Protection of ethnic kin, e) Tit-for-tat. Some of them are especially interesting to study in the Colombian case, but not all of them are applicable; for instance the reasons of protection of ethnic kin and irredentism are not applicable in the Colombian conflict. Conversely, the regime disputes reason requires responsible handling, particularly if ideological empathy between rebel groups and neighboring states appears in the context; also the mistreatment of Colombian migrants appears as a governmental strategy. Indeed, the ongoing diplomatic tension between Venezuela and Colombia promoted by Nicolas Maduro's decision of closing the border zone accompanied by forcing more than 1,000 Colombian migrants to leave Venezuela (El Espectador, 2015) should encourage an elaboration on the means used by the Venezuelan government to resolve internal political crises; i.e., discursively using the Colombian conflict and the stigmatization of Colombians as collaborators of paramilitary groups as an important cause of the Venezuelan crisis.

Additionally, it is particularly important to consider regional contexts in which policy transitions in neighboring countries have been taking place over the last part of 1990s and the beginning of $21^{\text {st }}$ century. According to Hengre et al (2001) empirical analysis, based on data from 152 countries in the period 1816-1992, linked levels of democracy and regime change, while exploring the implications of the direction and magnitude of political change, indeed "regime change leads to a heightened risk of civil war in the short run [...] consistent democracies and stark autocracies are equally unlikely to experience civil war. An intermediate regime is estimated to be four times more prone to civil war than a consistent democracy" (Hegre et al., 2001, pp. $35,38)$. Taking these authors' standpoints into 
account in order to analyze Bolivia, Ecuador, Nicaragua and Venezuela, remains an interesting avenue for future research since these countries have recently passed through regime transitions. It should be noted that it does not mean that the current transitional changes in the neighboring countries are linked and/or affecting the Colombian conflict dynamic. Instead, analyzing the mentioned countries' cases from Hegre et al lenses could academically allow us to elaborate on the meaning of democracies, anocracies or semi-democracies and stark autocracies, and their applicability in the neighborhood.

\section{THE ROLE OF TERRITORIAL PROXIMITY IN UNSOLVED BORDER DISPUTES CONTEXTS}

Within the literature on interstate conflicts, the roles of territory and geography in the occurrence of this type of conflict have captured the attention of conflict scholars, giving rise two major perspectives: the first set of perspectives views territory as a "source of conflict", while the second views territory as a "facilitating condition for conflict". For instance, Hensel (2000) suggests that conflict is more likely between neighboring states in circumstances of territorial controversies, while it is less likely between states with such a dispute but distant from each other. Therefore, territory is significant to the extent that it contributes to proximity between the states, i.e., proximity facilitates force projection capabilities, threat perception, but also interaction opportunities (Hensel, 2000, p. 5). In fact, Hensel found that: over half of all militarized disputes between 1816-1992 and two-thirds of all full- scale interstate wars in this period began between at least two contiguous adversaries, where contiguity is measured by the existence of a direct land or river border between two states [...] over half of all militarized disputes and almost every full-scale war in the 1945-1992 period began between at least one pair of contiguous adversaries [Indeed,] competing claims to 71 distinct pieces of territory [took place] in the Western Hemisphere (North, Central, and South America and the Caribbean) between 1816-1996 (Hensel, 2000, p. 8).

In line with this approach, Hensel, Vasquez and Valeriano (2008) established that between 1816 and 1997, the wars between neighboring countries represent $54 \%$ of the total wars initiated by states. Furthermore, the authors proposed a scientific typology and classification for all interstate wars from 1816-1997; and a classification for the interstate causes, showing three types of causes: a) territorial disputes, b) policy wars and c) political regime change. On the topic of territorial disputes, the authors specified "two neighbors have a higher probability of going to war than any other two states if their borders have not been mutually accepted" (Vasquez \& Valeriano, 2008, p. 9). However, by grasping how the later findings can be applied to the Colombian conflict, it can be found that the relationship between Ecuador and Colombia represents an important case in which to test Vasquez and Valeriano arguments. In fact, Colombia and Ecuador maintain strained relationships and they have defined territorial borders; therefore, the probability of war in this case would not be related to the mutu- 
ally accepted borders factor. In addition, the relationships between Colombia and Brazil or Peru are also illustrative, since their territorial proximity and political distance have not necessarily led to strained relationships and/ or to warnings of increases of interstate war. As a result, the territorial disputes, territorial proximity and political distance factors are applicable in certain cases. Further attention to the mentioned cases would argument insight into the applicability of those factors in both contemporary conflicts, i.e., interstate and intrastate.

The previous findings stress the importance of the foreign policy mandate regarding collaborative bilateral relations with neighboring countries. Fortunately, this is in line with the current Colombian foreign policy approach toward deepening of collaborative relations with: a) territorial neighbors: Brazil, Ecuador, Panama, Peru and Venezuela, b) Caribbean sea neighbors: Dominican Republic, Haiti, Jamaica, Honduras, Nicaragua, Costa Rica, Panama and Venezuela, and c) Pacific ocean neighbors: Costa Rica, Panama, and Ecuador. In addition, the previous emphasis lead to taking approaches which include both conflict prevention perspectives and cooperative interactions, given that:
[C]onflict is most likely when the expected utility of conflict is greatest that is, in the middle, where states have both the opportunity and willingness to engage in conflict [...] Proximity both creates such possibilities and raises their probabilities (and also raises the probability of cooperative interactions under the right circumstances) (Harr, 2005, p. 397).

If there is still doubt about these perspectives, at minimum it cannot be ignored that "territory [has] 'a psychological importance for nations that is quite out of proportion to its intrinsic value, strategic or economic', and territorial disputes are seen as arousing sentiments of pride and honor more rapidly and more intensely than any other type of issue [...] because of their tangible, intangible, and/or reputational importance" (Hensel, 2000, pp. 5-4).

As discussed above, continuous analyzing and actualizing knowledge about contiguous states are essential for interstate conflict prevention, but also for identifying shared interstate opportunities. This is particularly determinant for non-settled territorial bordering disputes in which stained relationships with distancing in mutual understanding terms between the states appear. In the Colombian case, it applies to Nicaragua ${ }^{25}$ and

25 The Esguerra - Bárcenas Treaty was signed between Colombia and Nicaragua in 1928, in which Nicaragua recognized Colombia's sovereignty over the San Andrés, Providencia and Santa Catalina archipelagos, while Colombia recognized Nicaragua's sovereignty over the Mosquitos Coast and the islands Mangle Grande and Mangle Chico. In 2001, Nicaragua presented their formal complaint to the International Court of Justice (ICJ), claiming their sovereignty over the east of longitude 82, including the archipelago of San Andrés. In 2007, the ICJ recognized the full sovereignty of Colombia over the islands of San Andrés, Providencia and Santa Catalina, but questioned the demarcation of the maritime boundary in the meridian 82. In 2012, the ICJ ruling was to grant Colombia full access to the continental shelf and the exclusive economic zone corresponding to the main archipelago of San 
Venezuel ${ }^{26}$. Likewise, those states that have not signed a territorial settlement treaty, i.e., Honduras $^{27}$ and Costa Rica ${ }^{28}$ with whom Colombia maintains harmonious relationships, should not be forgotten regardless of the current decreased risk of interstate conflict.

It is also argued that proximity is multidimensional, since it is linked to the distance that exists between social unit-states, and distance in turn can be measured in terms of "physical and psychological distances - technological and strategic, intellectual and legal, social and political, psychic and expectancy, and policy distances" (Starr, 2005, p. 390). Indeed, an alternative perspective is raised by Wrigth who suggests that the probability of war increases with increases of the distance -not proximity- in mutual understanding terms, between the states. In other words, war takes place when the powers are distanced from each other and a basis of understanding is absent. Exemplifying cooperation initiatives in which Colombia has been participating, handling the spillover effects of the internal conflict while facing multifactorial tensions that hamper relationships in the region, the following initiatives should be emphasized: the joint military base in Panama, the Binational Plan between Colombia and Ecuador, the Center against Smuggling coordinated with Venezuela, and the Brazilian Surveillance System of the Amazon (Sivam).

From the later approach angle, the renewed scope assumed by the Santos Calderon presidency is a tremendous challenge, i.e., continuously rebuilding and re-signifying the distanced perceptions between Colombia and the neighboring countries.

Andres, Providencia and Santa Catalina, plus 12-mile enclaves around the smaller islands, which, quite literally might now become islands within Nicaragua's ocean. Despite this ruling, there is still a discrepancy. See: http:// www.sogeocol.edu.co/Ova/fronteras_colombia/fronteras/caribe/caribe_nicaragua.html and http://www.nicaraguadispatch.com/news/2012/11/nicaragua-celebrates-world-court-ruling/6067

26 The dispute refers to the possession of the Monks Islets and the delimitation of marine areas on Coquibacoa Gulf. In 1941 a treaty on territorial border demarcation was signed in Bogota city. In 1952 the Colombian Foreign Minister Juan Uribe Holguín, gave to Venezuela the Monks Islets through a note, while disowning the $3^{\text {rd }}$ Article of the Colombian Constitution which establishes that borders can be changed only by a treaty or agreement approved by the Congress of the Republic. From 1954 direct negotiations began between the two governments in order to reach an agreement on the delimitation of marine and submarine areas. In 1958, the first United Nations Conference on the Law of the Sea established the matter of marking shared waters. Colombia welcomed to this agreement, but Venezuela did not.

27 The López Ramírez - Ocampo Contreras Treaty establishes marine and submarine areas. It was signed in 1986, has not yet been approved by neither the Congress of Colombia nor the Congress of Honduras. The border between Colombia and Honduras begins on the 82 meridian's intersection with the parallel 1458 '00 “. See: http://www. sogeocol.edu.co/Ova/fronteras_colombia/fronteras/caribe/caribe_honduras.html

28 The Fernández - Facio Treaty "on delimitation of Marine and Submarine Areas and Maritime Cooperation in the Caribbean Sea" was signed in 1977. It was approved by the Colombian Congress of Colombia in 1978, but the Legislative Assembly of Costa Rica has not. See: http://www.sogeocol.edu.co/Ova/fronteras_colombia/fronteras/ caribe/caribe_costarica.html> 


\section{GATHERING THE PIECES: ADDRESSING THE LINKS}

As is now well documented, different elements associated to dynamics surrounding the internal conflict have been involved in the Colombian internal conflict, which according to findings of international and national studies on conflict increases the likelihood of international disputes occurrences and the risk of escalation of both types of conflicts. Elements have involved intervention and externalization strategies, unexpected spillover effects of the internal conflict, contiguity and unsolved border disputes between neighboring states, long periods of a distanced basis for mutual understanding between contiguous states, the use and abuse of bordering zones by Colombian armed illegal groups and their allies in other countries, but also events of the alleged incursions of Venezuelan Bolivarian National Armed Forces in Colombian territory have been investigated by the Colombian government.

Each of the involved elements is a puzzling issue itself, consequently, when combining the real issues at stake (nature, meaning) they get more complex. Moreover, the simultaneous appearance of these elements increases the likelihood of interstate disputes in the region, due to the greater explanatory power of certain variables when understanding how an internal conflict may turn into an interstate conflict. In the Colombian case, the increased risk of intestate conflict is accompanied by powerful factors: a) the unexpected spillover effects of the internal conflict which derives in unsolved common problems and negatively affects national interests and/or the wellbeing of the citizens in the border areas, b) the contiguity and unsolved border disputes between neighboring states who have a distanced basis for mutual understanding based on distancing, and c) the use and abuse of bordering areas by Colombian armed illegal/criminal groups and their allies in other countries. The later factor represents a key issue during the Colombian post-conflict stage, due to the interests at stake. For example, profitable enterprises of crime and their well-rooted businesses in the globalized world will simultaneously be confronted by the willingness of the FARC and ELN demobilized members, and nourished by those who continue in the business such as criminal gangs, their territorial power protection and their links with other criminal groups within the American continent and abroad. Furthermore, the evolution of security performance in the border areas between Colombia and its neighbors might still face obstacles after the demobilization of the FARC provided the legacies of their activities, the presence of the ELN and criminal gangs. According to Valenzuela (as cited in Rosario University, 2015), one of the post-conflict challenges in Colombia is found in military and security fields, as there are many difficulties in weapons dereliction and reintegration processes. Indeed, Valenzuela argues that different scenarios which hamper those processes arise, among them: a) the possibility that not all guerrillas' armament may be delivered, b) guerrilla factions will remain in the mountains, c) criminal groups 
will be created, d) the possibility that not all FARC members will be demobilized (Rosario University, 2015).

For those reasons, realizing the post-conflict scenarios, their magnitude and challenges in the current regional context is more than pertinent, as is the importance of an uninterrupted encouraging of mutual understanding between the states, since they all have been affected in different degrees. The neighboring countries have been affected by collateral effects of the internal conflict, while Colombia has been affected by phenomena occurring in the neighboring countries which have impact on the dynamics generated by the Colombian illegal armed groups. Seen from this bifocal lens, with the intermestic nature of the internal conflict within interlocking domesticinternational arenas, one becomes aware that "civil wars are central to the motivations and strategies behind international disputes [...] civil wars provide new sources of interstate tension, and support for rebel organizations can complement or substitute for the direct use of force between states" (Gleditsch et al., 2008, p. 502).

As stressed in my introduction, the aim of this paper is in part achieved, but it is still under construction since going further and identifying shared challenges in the region is required. Since identifying the common points and shared regional challenges are key goals in the middle of proxy distances between states, one of the common issues and regional challenges is represented in the negotiated settlement of the Colombian internal conflict.

The following section examines current status of the Colombian peace process and goes further by proposing its resolution as a shared regional issue while other related issues are involved and deserve responsible handling.

\section{THE CURRENT PEACE PROCESS, A HISTORICAL OPPORTUNITY AT LOCAL, NATIONAL AND REGIONAL LEVELS}

In an ongoing peace process which started at the end of 2012, despite the hope that arises from the new chance for peace, it is important to keep in mind that civil wars rarely end in negotiated settlements. According to Walter (1997), 20\% percent of civil wars were resolved at the bargaining table between 1940 and 1990. Additionally, Fisas (2014) asserts that $80 \%$ of the 54 conflicts that ended in the last thirty years were possible through a peace agreement while $20 \%$ ended with military victory. The fact that civil wars tend to end on the battle field poses a startling empirical puzzle for the stakeholders and actors which are called upon to be a part of the Colombian peace process. The point here is not to argue blindly in favor or against the process by avoiding the issues and dynamics at stake, nor the international cases learnings or failures; but simply to point out that the current process presents a big step toward peaceful local, national and regional futures. The role of international collaboration is illustrative, indeed, "for groups fighting civil wars almost always chose to fight to the finish unless an outside power stepped in to guarantee a peace agreement. If a third party agreed to enforce the terms of a peace treaty, negotiations always succeeded regardless of 
the initial goals, ideology, or ethnicity of the participants" (Walter, 1997, p. 334). This raises a series of challenges for preventing the latent risk of interstate disputes in the South American region, and the importance of supporting the current Colombian peace process and the resolution of the conflict. In order to contribute to understanding some of the current challenges at stake, I will broadly zoom in on the current peace process and the shift it represents toward regional constructive approaches. I will then attempt to suggest a possible approach on the state as a multilevel couch for social change regarding the internal conflict resolution.

\section{Overview of the current Colombian peace process (2012-?)}

After five decades of internal conflict, the failed previous negotiations and attempts to defeat the FARC and the ELN guerrillas, a political solution was finally advanced by the president of Colombia, Juan Manuel Santos. The formal peace talks with the FARC were opened in Oslo in October 2012 and continued in
Havana, Cuba. Talks began without a ceasefire, however a unilateral ceasefire was declared by the FARC in 2015 while the government agreed to suspend Airforce strikes. Currently, the representativeness of the delegates at the negotiation table brings hope in the historic and complex responsibility to strike a deal toward a sustainable peace.

The government negotiating team ${ }^{29}$ includes representatives from the private sector, the official military forces, politicians and government delegates. In comparison with previous Colombian peace processes, the current scenario seems to be favorable for achieving a peace agreement, since there appears a mixture of elements that together make a shift toward a political settlement. Among the elements, quoted by the International Crisis Group (2012), are: a) the skepticism toward the guerrillas remains widespread, b) the security forces are better aligned with the civilian leadership and represented at the negotiation table than in the past, d) with neither side likely to win by arms alone, both have shown a strong incentive to negotiate, e) the FARC are militarily weakened and perceive

29 The government negotiating team members: Humberto de la Calle, who is the coordinator and moderator of the negotiating team, Jorge Enrique Mora Rangel, a retired General of the Army Forces of Colombia, Oscar Naranjo, ex-National Police General chief, María Paulina Riveros, Human Rights Chief at the Ministry of Internal Affairs, and both Sergio Jaramillo (High Commissioner for Peace) and Frank Pearl (Commissioner for Peace) are the direct representatives of the president in the peace process with the FARC. On the other hand, in the FARC negotiations Commission are participating: Rodrigo Londońo Echeverri called "Timochenco" Commander in Chief of the Central command, Luciano Marín Arango called "Ivan Marquez" Spokesman and Commander of the Central High Command, "Andres Paris" high-ranking chief of the Eastern Bloc of the FARC and ex-negotiator during the peace process under Pastrana's administration, Marco Leon Calarca spokesperson of the FARC and counselor member of the Central High Command, "Ricardo Granda" international spokesman of the FARC, and the so-called sergeant Pascuas, one of the FARC founders in 1964. It is worth noting that this is the first time for Colombia that representatives of the official armed forces are included at the negotiation table. See Semana Review (2012). 
the current opportunity for participating in peace building as a means to participate in political arenas, f) the Colombian government maneuvers from a position of strength due to the military advantage, while the trustbuilding is accompanied by advances in public social policies toward equity and equality, g) the rights of victims are being taken into account, as Santos' administration has recognized the state's responsibility in some key human rights violations, but has also started to tackle problems directly concerning the guerrillas, such as rural development. Another key factor should be added, h) the active participation and endorsement of civil society, notably coming from rural and indigenous communities have been significantly stronger than for previous peace processes.

The peace process has been accompanied by advances in the domestic sphere; for instance, the adoption of the Victims and Land Restitution Law. In addition to this national achievement, and as asserted by the Colombian Vice-President in the Colombian report of the Working Group on the Universal Periodic Review:

[F]or the first time the ethnic minorities were consulted on three instruments that guaranteed their rights: The National Development Plan, the National Guarantee Program and the legislation regarding reparation and land restitution... The security effort in the last decade had transformed the country [...] $87 \%$ of the municipalities, comprising $86 \%$ of the population, had not suffered a single act of terrorism in 2012 [...] the core of the transitional justice system in Colombia was the rights of victims and the rights to truth, justice and reparation [...] a Victims Reparation Unit, a Land
Restitution Unit and a Center for Historical Memory had been established (un General Assembly, 2013).

Inside this transformed context, and with the help of Norway and Cuba and the participation of Venezuela and Chile as observers, president Santos initiated the dialogue with the FARC. The peace process has been designed for taking as a flexible guide three stages (Semana Review, 2012). The first stage took place between February and August, 2012, in Cuba, where there was a common agenda to end the conflict. The second began in Oslo, which was then moved to Havana, and allowed defining the five major issues to be discussed. The final stage is thought to lead to face instrumentation, cease of hostilities, demobilization, the implementation of the agreements, verification means, among others (Semana Review, 2012). Currently, five key issues have been defined: 1 . Agriculture Development, 2. Political participation, 3. End of conflict, 4. Illicit drugs, 5. Victims.

Considerable progress has been made to date in the peace process. In the words of president Santos (2015), three agreements were already reached on comprehensive rural development, political participation and solving the illicit drug problem. Additonally, a preliminary agreement on the basis of a justice system, which is the most difficult and complex topic in all peace processes held throughout the world, was determined by creating a "Special Jurisdiction for Peace" which is thought to be set up within the framework of the Colombian Constitution and laws, respecting the guidelines of international law to which Colombia is bound. "It is a jurisdiction 
that seeks, first and foremost, to satisfy the rights of the victims-in particular the right to justice, but also their rights to truth, reparation and non-repetition- [...] This is the first time that a government and an illegal armed group-in a peace agreement and not as a result of subsequent impositions-create an accountability system before a national tribunal for committing international and other serious crimes" (Santos, 2015).

\section{The state: a multilevel approach of social change in conflict contexts}

A transformed scenario, marked by an unsolved internal conflict and an ongoing peace process, in continuous definition by the agents of social change give rise to the necessity to reflect on the state's role(s). It challenges the definitions of the state and its supposed capabilities for promoting change. It is worthwhile noting that this issue is related to the domestic approach of the state, but also to the unavoidable relationship between international and domestic arenas and the simultaneous state performance on both. Keeping this in mind is imperative, since the Colombian internal conflict is a national and sovereign issue, while its incidence reaches both regional security and stability.

One of the possible entry points to deal with this puzzle is the proposal of Clapham, who dealt with the relationship between statehood and the international system. The author asserts that in cases of internal conflict in which the state loses the supremacy over some regions or attributes of the state are blurred, or in cases of incomplete degrees of statehood:
The common reaction, at the levels both of diplomatic practice and of intellectual analysis, has been to reassert the primacy of statehood. Such cases have been treated as 'collapsed states', in which 'legitimate authority' needed to be restored; or as 'failed states' which had to be 'saved', if need be through some form of United Nations conservatorship', even though the very considerable difficulties of this project also had to be recognized. Such aspirations reflect not only a diplomatic and intellectual preoccupation with the particular forms of political organization to which the international system has become accustomed, but also a normative concern for the consequences of collapse (Clapham, 1998, p. 156).

From this angle, the "common reaction" can be confronted within the current Colombian case, in two senses. First, legitimate authority does not need to be restored in the way suggested by the "collapsed states" concept, however, some regions in the country, due to the presence and activity of illegal armed groups, have relativized the character of legitimacy when it has been historically absent, therefore the presence of the state should be focused on achieving legitimacy through democratic institutional strategies and the rule of law. Likewise, the "failed state" concept is not applicable to the Colombian case, but some Colombian regions require more governance effort in order to achieve welfare and quality of life in a post-conflict society.

On a more strident note, the resignification process of the internal conflict is advancing. Shifts are taking place, from narrow focuses on the internal conflict to recognize the Colombian peace process as a means to prevent interstate conflicts in South America 
and rethinking regional security. Additionally, attempts to use the peace process as an opportunity for collaborative alliances have appeared.

Indeed, the role that is called for the state to play in the national and current scenarios is taking shapes that are favorable to social change, which in practice removes the convenient assumptions on what is feasible to be addressed by a state dealing with internal conflict. The Colombian state seems to be aware that the foundations for sustainable peace will ultimately need to lead to a wider social process to tackle the public problems within the country. The support required in practice will be defined by the extent to which the stakeholders, whether public or private, will be able and willing to participate at local, national, regional and global levels.

In a more globalized world, the collaboration between actors, multilevel governance is a key issue, and in order to achieve it the multilevel approach for social change seems to lead the state to adopt a "coach role". Indeed, such a role for the state results in revisiting inflexible state definitions. Therefore the possibilities and challenges at hand get wider, since coaching, as proposed by Beltran (2013), is the art of facilitating the performance, learning and development of another(s), and its purpose is to remove the obstacles that prevent individuals (actors) from achieving their objectives. However, the coach role is not reduced to a mere spectator, instead it promotes discussions, stirrings, provokes the raising of new approaches; a means of getting at the heart of the matter. If the matter here is the success of the Colombian peace process, being that the state had taken on similar characteristics of a constructive coach role and wanted to expand them, then the necessity of being assertive in figuring out which leadership role is required to approach each of the stakeholders at the local level, but also national, regional, international (global) levels. At the local level, the state needs to decide assertively which kind of leadership will be adopted in the interaction and dialogue with civil society, entrepreneurs, local landlords and the huge variety inside each of them, victims, public force personnel, civil servants, indigenous communities and other special population groups, and demobilized members of guerrillas. In doing so, it is necessary to identify and take into account what these actors need and what their expectations, interests and worries (fears) about the peace process are, but also their current disposition or motivation to get into the Colombia postconflict stage and their capabilities, knowledge and strengths for doing so. Therefore, governance at local level, surrounding the peace goal, might be expanded and made inclusive.

At the regional level, a key question arises regarding the weight of a coach role or which kind of name should be convenient to avoid misunderstandings for getting involved in the sovereign issues of each state. The point here, instead, is promoting a collective conscience, within Colombia and the neighboring states, about the Colombian peace process as a means to prevent interstate conflicts in South America and rethink regional security, but also as an opportunity for collaborative alliances to face the transnational dynamics at stake that affect Colombia and its neighbors' wellbeing. 
This might enhance reflecting on a relationship between "state coaches", the possibility of coaching within mutual understandings toward addressing the common issues identified by continuous analysis of what is at stake. If interstate conflict prevention in the South America region is at stake, and if the Colombian peace process success can be recognized as one of the collective interests in the region, the Colombian state should deeply consider what the internal dynamics (phenomena) which have been negatively impacting neighbor states are. Also, it is necessary to promote that neighboring states include into their agendas strategies which answer the question of what are they willing to do to reduce those factors. In doing so, each of the states might be a constructive coach within their societies to define specific strategies for addressing each of the identified factors. Thus, the states would need to decide assertively which kind of leadership would be adopted in interaction and dialogue processes. These processes might collectively lead to identify national and regional factors directly related to the current national security strategies; moreover, this process might lead to a reflection on their effectiveness and efficiency according to current challenges.

\section{FINAL REMARKS}

What can we conclude from this analysis? Firstly, the Colombian internal conflict has passed through different stages and has been marked by the dynamics of the involved actors, but also by inconsistent presidential administration strategies. Indeed, the Colom- bian official anti-insurgency strategy has been 'intermestic'; it is therefore understandable that the decision-making processes for each presidential administration was framed differently. Specifically, the governmental decision of either internationalizing the conflict or keeping it in domestic stage was strongly influenced by the current historical international contexts.

Secondly, international studies on internal conflicts pointed out decisive factors that had escalated to interstate conflicts are applicable in the Colombian conflict. In particular: a) illegal armed groups and their financing sources, b) intervention, externalization strategies and collateral effects, c) the role of territorial proximity on the border zones in certain cases, d) the contiguity and unsolved border disputes between neighboring states when there is a distanced basis for mutual understanding, $\mathrm{g}$ ) periods of a distanced basis for mutual understanding between contiguous states, h) the use and abuse of bordering areas by Colombian armed illegal groups and their allies in other countries.

Regarding the rationale of illegal armed groups and their financing resources, although natural resources ease the emergence of illegal armed groups, they themselves do not have sufficiently explanatory power to understand the Colombian case. In fact, the armed confrontation in Colombia has not been framed in a linear evolution, the presence of resources and funding sources in the guerrillas' influence areas have been determined according to their strategic behavior and territorial control needs, which are not exclusively due to an economic rationale. Although this applies to 
Colombian guerrillas, it is not the case for the euphemistically called "paramilitary/selfdefense groups" and their descendant "criminal gangs". Nevertheless, drug trafficking as an important source of financing of all the illegal armed groups makes it more challenging to face the complexity of the resolution of internal conflict. This in turn leads to the necessity to rethink the current war on drugs, a key issue for Colombia, Mexico, Guatemala, but also for the South American region and all regions affected by this ineffective strategy.

In addition, the emphasis given to strategies of intervention and externalization, and unintended spillover effects from internal conflict, have been present in the Colombian conflict. Indeed, events verified by the information found in the computer of a high Commander of the FARC showed the involvement of senior officials from neighboring countries and dynamics in those states and their links with the FARC, but also links with this guerrilla and actors in 30 countries.

Additionally, given the role of territorial proximity in the occurrence of interstate conflicts (see Hensel, 2000; Vásquez and Valeriano, 2008; Harr, 2005), conflict is more likely between proximate states and two neighbors have a higher probability of going to war than any other two states if their borders have not been mutually accepted, in certain cases. It is important for Colombia to promote continuous and collaborative relationships with: a) territorial neighbors: Brazil, Ecuador, Panama, Peru and Venezuela, b) Caribbean sea neighbors: Dominican Republic, Haiti, Jamaica, Honduras, Nicaragua, Costa Rica, Panama and Venezuela, and c) Pacific ocean neighbors: Costa Rica, Panama, and Ecuador. This is particularly decisive for the non-settled territorial bordering disputes with Nicaragua and Venezuela, with whom there is a lack of mutual understanding.

Thirdly, zooming in on a challenge that should be faced in preventing conflict, the statement of Starr (2005, p. 400) should be underlined: "not only to look at the presence or absence of contiguity (especially as a "control" variable) [...] but how territory is viewed by leaders, populations, and relevant subsets of these populations. The spatial distribution and locations of such subsets of people should be examined as well". Indeed, the role of the leaders/decision makers' perspectives about territory and sovereignty is crucial, since those approaches can justify, more than any other issues, the escalation of disputes in the name of protecting or promoting national interests (Hensel, 2000).

Fourthly, the fact that civil wars tend to end on the battlefield poses a startling empirical puzzle for the stakeholders and actors that are called upon to be a part of the Colombian peace process. However, the current process presents a big step toward local, national and regional peaceful/shared futures. This raises a series of challenges for preventing the latent risk of interstate disputes in the region and the importance of supporting the current Colombian peace process and the resolution of the conflict. Nowadays, the peace process presents a mixture of elements that combine making a shift in the political settlement.

From a long term view position, it is strategic to keep in mind that the Colombian internal conflict is a national and sovereign 
issue, and its incidence reaches both regional security and stability. Also, the nature of conflict demands going further than traditional approaches which cannot respond wisely to the current inter-connected scenarios and challenges. Undeniably, it is necessary to advance with more effort on the resignification of the internal conflict toward recognizing the Colombian peace process as a means to prevent interstate conflicts in South America and rethinking regional security. This is in line with realizing the opportunity that the latter gives to raise collaborative alliances in facing those transnational dynamics at stake that affect Colombia and its neighbors, i.e., greater collateral effects and damages might occur in the bordering areas where illegal groups have rooted their profitable activities if regional and binational strategies are not effectively implemented in the short term and during the potential post-conflict stage. Therefore, the role that is called for the states to play in the national and current scenarios removes convenient assumptions on what is feasible to be addressed by states dealing with internal armed conflicts.

Fifthly, by taking into account the social changes which are taking place in Colombia, and the social changes that the peace process gives rise to, I suggest that the Colombian state needs to act simultaneously at different levels and use suitable means and approaches for each one of them. It seems that a multilevel approach for social change is being adopted by the state, but it might also be expanded toward adopting a coach role, which is itself challenging.
In the meantime, the lack of resolution of the Colombian internal armed conflict increases the likelihood of interstate conflicts in the South American region, since there are some characteristics that tend to result in a nexus between intra and interstate conflicts. However, preventing the latent risk of interstate disputes seems to be possible by way of supporting the current Colombian peace process and the resolution of the conflict. From this recognition, care needs to be taken to ensure responsible and ethical paths in which multilateral, national and local actors will respond and perceive to what extent they have to be involved.

As a further direct linkage, the Colombian state recognition on the existence of the internal conflict, jointly with the current foreign policy re-definition, represents an important opportunity for regional stability. Proximity promotes the possibility while increasing conflictive interactions in certain cases, but also cooperative, as was pointed out by Starr (2005, p. 397) "high levels of ease of interaction across borders - greater interaction opportunities- are also related to positive Deutschian interdependence-integration effects [...i.e.,] that increased interactions, transactions, and interdependence makes conflict less probable". In this sense, the reconceptualization of the internal conflict, both domestically and internationally, requires constructive willingness from the neighboring states and their presidential administrations. Therefore, responding to the very nature of the challenges that the internal conflict imposes might be achievable. This is particularly important, since "Dyadic territorial wars are 
the typical wars in the system [...] territory is not only a key to understanding the most prevalent wars in the system, but also a key to creating a much more peaceful world if that class of war can be eliminated" (Vasquez \& Valeriano, 2008, p. 26).

Although there are theories for explaining the nexus between internal conflicts and interstate conflicts, we still need to develop theories about the nexus between internal conflicts contexts and interstate cooperation. Theories about the nexus between peace processes and interstate conflicts prevention are required. But it is also required to go deeper into how the global war on drugs impacts the internal conflicts dynamics all over the world, and to a new global discussion about the war, to deal with how we should build security strategies from the regional lens and then articulate them. These issues deserve further research in order to progress toward preventive means for interstate conflicts at the regional level, but also facultative means for expanding the scope of interstate cooperation in facing the shared problems and current challenges at stake.

\section{REFERENCES}

Bagley, B. (2000). Narcotráfico, violencia política y política exterior de Estados Unidos hacia Colombia en los noventa. Revista Colombia Internacional, 49-50.

Bell, G., Borda, S., Gómez, H. J., Ramírez, S., Reina, M., Reyes, C. and Tokatlian, J. (2010). Misión de Politica Exterior: Informe Final. Bogota: Ministerio de Relaciones Exteriores/Fedesarrollo,
Beltran, M. (2013). Couching process: informal interview. Bogotá.

CINEP (2004). Mercenariato internacional en el paramilitarismo colombiano. In Paramilitarismo de Estado en Colombia 1988-2003. Bogota: CINEP.

Clapham, C. (1998). Degrees of statehood. Review of International Studies, 24, 143-157.

Echandía, C. (2006). Dos décadas de escalamiento del conflicto armado en Colombia 1986-2006. Bogota: CIPE / Universidad Externado de Colombia.

Echandía, C., Bechara, E. and Cabrera, I. (2010). Colombia: estado del conflicto armado al final de la administración de Álvaro Uribe. In Anuario 2010 de la seguridad regional en América Latina y el Caribe (pp. 136-172). Bogota: FESCOL.

El Espectador (2015). Colombianos expulsados de Venezuela buscan reencauzar sus vidas. El Espectador.

Fisas, V. (2014). Conflictos y procesos de paz contemporáneos. Retrieved from http://www.arcoiris. com.co/2014/05/conflictos-y-procesos-de-pazcontemporaneos/

Geographical Society of Colombia (2002). Colombia zonas de frontera. Retrieved from http://sogeocol.edu.co/Ova/fronteras_colombia/fronteras/ zona.html

Gleditsch, K., Skrede, I. and Schultz, K., (2008). Fighting at Home Fighting Abroad: How Civil Wars Lead to International Disputes. Journal of Conflict Resolution, 52 (4), 479-506.

Hegre, H., Ellingsen, T., Gates, S. and Gleditsch, N. (2001). Towards a Democratic Civil Peace? Democracy, Political Change and Civil War 1816 -1992. American Political Science Review, 95 (1), 34-48.

Hensel, P. (2000). Territory: Theory and Evidence on Geography and Conflict. In Vásquez, J. A. (ed.). What do We Know about War? (pp. 57-84). New York: Rowman y Littlefield. 
International Crisis Group (2012). Colombia: Peace at Last? Latin America Report 45.

Instituto de Estudios Geoestratégicos y Asuntos Políticos de la Universidad Militar Nueva Granada (2010). Evaluación de la Política de Defensa y Seguridad Democrática, 2002-2010. Serie Informativo: Frente Interno, 71, 1-16.

Le Billon, P. (2001). The Political Ecology of War: Natural Resources and Armed Conflicts. Political Geography, 20 (5), 561-584.

Long, N. (2004). Development sociology: actor perspectives: Introduction. London: Routledge, 1-6.

Manning, B. (1997). The Congresss, the Executive, and intermestic Affairs: Three proposals. Foreign Affairs, 55 (2), 306-320.

Merry, S. (1988). Legal Pluralism. Law \& Society Review, 22, 869-896.

OASIS (2008). La inserción internacional de Colombia: hacia la construcción de una politica exterior para el siglo XXI. Bogota: Universidad Nacional de Colombia/Proyecto Piensa Colombia.

Pardo, R. \& Carvajal, L. (2004). Relaciones internacionales, conflicto doméstico y procesos de paz en Colombia. In Londoño, P. Violencia, paz y politica exterior en Colombia (pp. 153-233). Bogota: Universidad Externado de Colombia,

Ramírez, S. (2006). El Gobierno de Uribe y los países vecinos. Análisis político, 57 (19), 65-84.

Roy, N. (1999). Third World In The Age Of Globalisation, The: Requiem Or New Agenda? New Dehli: Madhyan Books.

Santos, J. (2015). Address by president Juan Manuel Santos about the agreement on justice matters in the peace Process with the FARC (v.12). La Habana.

Smulovitz, C. (2005). Inseguridad y el miedo de la ciudadanía: respuestas públicas y privadas en Argentina. In Frühling, H. \& Tulchin, J. (eds.).
Crimen y violencia en América latina. Bogota: Fondo de Cultura Económica.

Semana Review (2012). Diez puntos clave del proceso. Retrieved from http://www.semana.com/ politica/articulo/diez-puntos-clave-del-proceso/266501-3 LINK

Semana Review (2009). El Mundo de las FARC. Retrieved from http://www.semana.com/nacion/mundofarc/119209-3.aspx

The Guardian (2016). After 30 years on the frontline, Colombia looks beyond the failed war on drugs. The Guardian.

The National Memory Center of Colombia (2013). Informe ;Basta Ya! Colombia: memorias de guerra y dignidad. Bogotá: Centro Nacional de Memoria Histórica.

UNCTAD (2009). Rethinking the Role of the State in LDCs Towards Development Governance. In The Least Developed Countries Report 2009 The State and Development Governance. New York and Geneva: United Nations Publications.

uN General Assembly (2013). Draft report of the Working Group on the Universal Periodic: Colombia. Human Rights Council, Working Group on the Universal Periodic Review, Sixteenth session, Geneva.

UNODC (2012). Recent Statistics and Trend Analysis of Illicit Drug Markets. In World Drug Report 2012. New York: United Nations publications. Rosario University (2015). Memorias Foro: Retos y encrucijadas del posconflicto en Colombia. Bogota: Universidad del Rosario.

Vásquez, J. \& Valeriano, B. (2008). Classification of Interstate Wars. Illinois: University of Illinois.

Vice-Presidency of the Republic of Colombia (2011). Focos y continuidad geográfica de la presencia activa de las FARC 1198-2011. In Observatorio Derechos Humanos. Retrieved from http://www. 
derechoshumanos.gov.co/Observatorio/Documents/Geografia-Violencia/Geografia-presenciaactiva-farc-1998-2011.pdf

Vice-Presidency of the Republic of Colombia (2006).

Focos y continuidad geográfica de la presencia activa de las AUC 2000-2006. Observatorio Derechos Humanos. Retrieved from http://www. derechoshumanos.gov.co/Observatorio/documents/2010/090623/GEOGRAFIA\%20DE\%20 LA\%20PRESENCIA \%20ACTIVA \%20\%20DE $\% 20$ LAS\%20AUTODEFENSAS.pdf

Vice-Presidency of the Republic of Colombia (2011). Focos y Continuidad geográfica de la presencia activa del ELN 1998-2011. Observatorio
Derechos Humanos. Retrieved from http://www. derechoshumanos.gov.co/Observatorio/Documents/Geografia-Violencia/Geografia-presenciaactiva-ELN-1998-2011.pdf

Vice-Presidency of the Republic of Colombia (2005). Dinámica espacial de las muertes violentas en Colombia 1990-2005. Programa Presidencial de Derechos Humanos y DiH. Retrieved from http://www.acnur.org/pais/docs/2551. pdf?view=1

Walter, B. (1997). The critical barrier of civil war settlement. International Organization 5, 335-364.

Wood, E. J. (2003). What we don't know about civil wars. Global Governance, 9 (3), 247-260. 